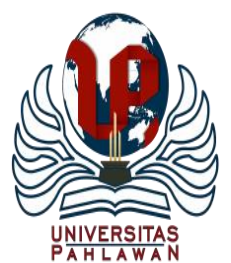

Edukatif : Jurnal Ilmu Pendidikan Volume 3 Nomor 4 Tahun 2021 Halm 2372 - 2382

EDUKATIF: JURNAL ILMU PENDIDIKAN

Research \& Learning in Education

https://edukatif.org/index.php/edukatif/index

\title{
Pengembangan Media Pembelajaran Audio Visual Berbasis SAVI untuk Meningkatkan Prestasi Lompat Jauh Gaya Jongkok (Gaya Ortodok) Siswa Sekolah Menengah Pertama
}

\author{
Destu Kurniawan $^{1 凶}$, Dwi Yulianti ${ }^{2}$, Riswandi $^{3}$ \\ Program Studi Magister Teknologi Pendidikan Universitas Lampung, Indonesia ${ }^{1,2,3}$ \\ E-mail : destukurniawan31@gmail.com ${ }^{1}, \underline{\text { Safira_shodiq@yahoo.com }}{ }^{2}, \underline{\text { riswandi.unila@ gmail.com }}{ }^{3}$
}

\begin{abstract}
Abstrak
Tujuan penelitian ini untuk mengembangkan media pembelajaran materi atletik lompat jauh gaya jongkok (gaya ortodok) kelas VIII SMP N 1 Ambarawa. Pengembangan media pembelajaran dilatar belakangi oleh kebutuhan pembelajaran yang dapat meningkatkan kualitas pembelajaran. Jenis penelitian ini adalah penelitian pengembangan (research and development/R\&D). Tahapan utama dalam penelitian dan pengembangan ini adalah (1) pengumpulan informasi dan penelitian pendahuluan; (2) perencanaan; (3) pengembangan produk; (4) pengujian terbatas, dan (5) revisi produk akhir. Populasi dalam penelitian ini adalah peserta didik kelas VIII SMP N 1 Ambarawa. Teknik pengambilan sampel yang digunakan adalah teknik purposive sampling. Sampel penelitian adalah 5 (Lima) guru dan 5 peserta didik kelas VIII SMP N 1 Ambarawa. Teknik pengumpulan data menggunakan observasi dan angket. Teknik analisis data dalam penelitian ini menggunakan teknik analisis deskriptif kualitatif. Berdasarkan hasil penelitian dan pembahasan dapat disimpulkan bahwa pengembangan pengembangan media pembelajaran audio visual berbasis SAVI untuk meningkatkan prestasi lompat jauh gaya jongkok (gaya ortodok) pada siswa SMP kelas VIII layak untuk digunakan dalam pembelajaran. Hal tersebut berdasarkan hasil validasi ahli materi sebesar $92,5 \%$, hasil validasi ahli desain sebesar 91,5\%, hasil validasi ahli media sebesar 88,75\%, hasil tanggapan kepada guru sebesar 91,30\%.
\end{abstract}

Kata Kunci : Vidio pembelajaran, atletik lompat jauh gaya jongkok, SAVI.

\begin{abstract}
The purpose of this study was to develop learning media for long jump athletics for class VIII SMP N 1 Ambarawa. The development of learning media is motivated by learning needs that can improve the quality of learning. This type of research is research and development $(R \& D)$. The main stages in this research and development are (1) information gathering and preliminary research; (2) planning; (3) product development; (4) limited testing, and (5) final product revision. The population in this study were students of class VIII SMP 1 Ambarawa. The sampling technique used is purposive sampling technique. The research sample was 5 teachers and 5 students of class VIII SMP 1 Ambarawa. Data collection techniques using observation and questionnaires. The data analysis technique in this study used a qualitative descriptive analysis technique. Based on the results of research and discussion, it can be concluded that the development of savi-based audio-visual learning media development to improve long jump achievement of the squat style in class VIII SMP students is feasible to use in learning. This based on the results of material expert validation of 92.5\%, design expert validation results of $91.5 \%$, media expert validation results of $88.75 \%$, and $91.30 \%$ responses to teachers.
\end{abstract}

Keywords : Learning video, squat long jump athletics, SAVI.

Copyright (c) 2021 Destu Kurniawan, Dwi Yulianti, Riswandi

$\triangle$ Corresponding author

Email : destukurniawan31@gmail.com

DOI : https://doi.org/10.31004/edukatif.v3i4.1119

ISSN 2656-8063 (Media Cetak)

ISSN 2656-8071 (Media Online)

Edukatif : Jurnal Ilmu Pendidikan Vol 3 No 4 Tahun 2021 p-ISSN 2656-8063 e-ISSN 2656-8071 
2373 Pengembangan Media Pembelajaran Audio Visual Berbasis SAVI untuk Meningkatkan Prestasi Lompat Jauh Gaya Jongkok (Gaya Ortodok) Siswa Sekolah Menengah Pertama - Destu Kurniawan, Dwi Yulianti, Riswandi

DOI $\quad$ : https://doi.org/10.31004/edukatif.v3i4.1119

\section{PENDAHULUAN}

Pendidikan di Indonesia memiliki tujuan untuk memberikan pengetahuan, pemahaman, serta pengajaran. Pernyataan tersebut tertuang dalam undang-undang No. 20 tahun 2003 Bab 1 Pasal 1 tentang Sistem Pendidikan Nasional, yang menyebutkan bahwa pendidikan adalah usaha sadar dan terencana untuk mewujudkan suasana belajar dan proses pembelajaran agar peserta didik secara aktif mengembangkan dirinya untuk memiliki kekuatan spiritual keagamaan, pengendalian diri, kepribadian kecerdasan, akhlak mulia, serta keterampilan yang diperlukan dirinya, masyarakat bangsa dan Negara. Pendidikan merupakan investasi penting yang menentukan masa depan bangsa.

Atletik merupakan aktivitas jasmani yang efektif untuk mengoptimalkan pertumbuhan dan perkembangan anak. Gerakan-gerakan atletik sangat sesuai untuk mengisi program pendidikan jasmani, seperti lari, lompat, jalan, dan lempar. Di samping itu, atletik juga berpotensi mengembangkan keterampilan gerak dasar, sebagai landasan penting bagi penguasaan keterampilan teknik cabang olahraga. Dimasukkannya cabang olahraga atletik hingga di sekolah-sekolah dalam mata pelajaran Pendidikan Jasmani ini, sudah selayaknya membawa angin segar untuk meningkatkan motivasi siswa untuk mengikutinya.

Lompat jauh adalah suatu bentuk gerakan melompat yang diawali dengan gerakan gerakan horizontal dan diubah ke gerakan vertical dengan cara melakukan tolakan pada satu kaki yang terkuat untuk memperoleh jarak yang sejauh-jauhnya (Wiarto, 2013: 32). Lompat jauh yang diajarkan di sekolah merupakan latihan bagi siswa untuk melakukan gerakan melompat dan mencapai jarak lompatan sejauh-jauhnya yang dimulai dengan gerakan lari sebagai awalan dalam melompat kemudian menolak pada papan tumpuan/ tolakan kemudian gerakan melayang di udara dan akhirnya mendarat pada titik terjauh ke dalam bak pasir sebagai media pendaratannya.

Menurut (Sugihartono, 2012: 74). mengemukakan bahwa belajar adalah suatu proses perubahan tingkah laku sebagai hasil interaksi individu dengan lingkungannya dalam memenuhi kebutuhan hidupnya. Pembelajaran materi atletik cabang lompat jauh merupakan materi yang bagi pendidik mata pelajaran penjaskesrek merupakan salah satu materi yang susah buat dipraktekan gerakannya. Karena, memerlukan teknik dan keahlihan khusus dalam penyampaiannya.

Menurut (Wijoyo \& Girivirya, 2020:51) guru dapat dikatakan profesional jika mampu memberikan pengalaman belajar sesuai dengan kebutuhan belajar peserta didik. Selain itu ada tugas utama pendidik pendidik; (1) guru harus memilki wawasan yang luas, sehingga peserta didik mendapatkan sesuatu yang baru untuknya dan tidak membosankan. (2) menciptakan pembelajaran yang menyenangkan dan menarik. (3) Memberikan evaluasi sesuai dengan kurikulum yang sudah ditetapkan. dan (4) Menyiapkan bahan pembelajaran (materi).

Kemajuan ilmu pengetahuan dan teknologi (IPTEK) semakin berkembang pesat akhir-akhir ini. Hal ini tersebut ditandai dengan banyak inovasi-inovasi baru yang muncul di berbagai ilmu. Olahraga merupakan ilmu yang terpengaruh oleh adanya teknologi untuk mendukung ketika melakukan suatu aktivitas tersebut. Olahraga prestasi merupakan aktivitas fisik yang dilakukan untuk mencapai target prestasi setinggi- tinginya. Olahraga prestasi dilaksanakan melalui proses pembinaan dan pengembangan secara terencana, berjenjang, dan berkelanjutan melalui kompetisi dengan dukungan ilmu pengetahuan dan teknologi (IPTEK) (Suherman, 2012: 12).

Pembelajaran yang ideal apabila dapat dilakukan dengan memperhatikan karakteristik peserta didik secara menyeluruh. Hal-hal yang perlu diperhatikan dalam pembelajaran adalah kebutuhan belajar dan lingkungan belajar peserta didik sehingga dalam prosesnya peserta didik dapat memaknai belajar sebagai pengalaman yang tidak bisa hilang dalam memori peserta didik. Tugas pendidik (guru) sebagai fasilitator adalah menciptkan sebuah lingkungan belajar yang kondusif jika suasana yang kurang atraktif dan tidak 
2374 Pengembangan Media Pembelajaran Audio Visual Berbasis SAVI untuk Meningkatkan Prestasi Lompat Jauh Gaya Jongkok (Gaya Ortodok) Siswa Sekolah Menengah Pertama - Destu Kurniawan, Dwi Yulianti, Riswandi

DOI : https://doi.org/10.31004/edukatif.v3i4.1119

melibatkan peserta didik dalam pembelajaran cenderung membuat suasana kelas ribut dan tidak terarah guru membutuhkan kehadiran alat/media pembelajaran untuk mengatasi berbagai hambatan yang dijumpai dikelas (Mallikharjuna, 2014: 143).

Hasil observasi menunjukkan bahwa pembelajaran lebih menerapkan teacher centered approaches yaitu pendidik menjadi pusat informasi bagi siswa, sehingga pembelajaran cenderung konvensional. Pola pembelajaran ini lebih kepada keaktifan pendidik dibandingkan dengan peserta didik. Selain itu, pendidik menganggap bahwa pembelajaran di kelas hanya untuk menuntaskan materi yang ada di buku saja. Peserta didik dipandang sebagai objek bukan sebagai subjek pembelajaran sehingga peserta didik kurang aktif dalam mengeksplorasi pengetahuan, Motivasi peserta didik dalam pembelajaran tidak baik, hal ini dapat dibuktikan ketika proses pembelajaran peserta didik cenderung membuat keramaian dan tidak fokus.

Berdasarkan hasil pengecekan dokumen pada tahun ajaran 2020/2021 ditemukan 17 dari 20 siswa telah mendapatkan nilai tidak tuntas dengan nilai rata-rata siswa adalah 65 sedangkan nilai KKM yang ditentukan adalah 75, artinya materi ini dianggap sulit oleh para peserta didik. Berdasarkan Persentase ini. Berdasarkan (Depdiknas, 2017) Persentase ini Ketidaklengkapan relatif rendah karena idealnya pembelajaran dikatakan berhasil jika minimal 75\% siswa mampu mencapai kriteria ketuntasan minimal.

Kehadiran media mampu memberi motivasi dan membangkitkan minat dan perhatian dari pembelajar terhadap materi (Ekiz \& Zahicjan, 2016). Penggunaan media pembelajaran ini untuk membantu terciptanya proses pembelajaran yang menarik dan menyenangkan. Media pembelajaran interaktif menarik perhatian peserta didik, merangsang peserta didik untuk belajar, sehingga pesan yang disampaikan dapat dipahami dengan baik. Dalam hal ini kehadiran media ini berupa media pembelajaran sebagai wahana untuk memenuhi kebutuhan dalam proses kegiatan pembelajaran atletik lompat jauh.

Media pembelajaran menurut (Sukariasih \& Erniwati, 2019) adalah media yang menggabungkan dua unsur atau lebih media yang terdiri dari teks, grafis, gambar, foto, audio, video dan animasi secara terintegrasi. Media pembelajaran terbagi menjadi dua kategori, yaitu: media pembelajaran linier dan media pembelajaran interaktif. Media pembelajaran linier adalah suatu media pembelajaran yang tidak dilengkapi dengan alat pengontrol apapun yang dapat dioperasikan oleh pengguna. Media pembelajaran ini berjalan sekuensial (berurutan), contohnya: TV dan film.

Media pembelajaran merupakan alat bantu yang dapat mendorong proses belajar dapat dilakukan di mana saja dan kapan saja. Media pembelajaran dapat dirancang sedemikian rupa sehingga peserta didik dapat melakukan kegiatan belajar dengan lebih leluasa dimanapun dan kapanpun tanpa tergantung seorang guru. Karakteristik Media pembelajaran yang dikembangkan mencakup unsur visual, audio dan audio visual. bahwa media pembelajaran adalah suatu sistem media yang didesain dari beberapa media dengan tujuan memberikan interaktif antara pengguna dan media. Beberapa media di dalamnya bertujuan agar pengguna lebih mudah memahami suatu topik bahasan tertentu. Media sebagai sumber belajar diakui sebagai alat bantu auditif, visual, dan Audio Visual.

Teknologi audio visual merupakan cara dengan menghasilkan atau menyampaikan materi menggunakan perangkat elektronik untuk menyajikan pesan-pesan Audio dan Visual. Pengajaran melalui audio Visual jelas bercirikan pemakaian perangkat keras selama proses belajar, seperti mesin projector film ataupun tayangan dengan menggunakan televisi dan (video compact disc) VCD. Jadi, pengajaran melalui media audio visual adalah produksi dan penggunaan materi yang penyerapanya melalui pandangan dan pendengaran serta tidak seluruhnya tergantung kepada pemahaman kata atau smbol-simbol yang senpa. Pengertian audio Visual menurut (Arsyad, 2015: 30) adalah produksi atau penggunaan materi yang penyerapannya nmelalui pandangan dan pendengaran serta tidak seluruhnya tergantung kepada pemahaman kata atau simbol - simbol serupa. 
2375 Pengembangan Media Pembelajaran Audio Visual Berbasis SAVI untuk Meningkatkan Prestasi Lompat Jauh Gaya Jongkok (Gaya Ortodok) Siswa Sekolah Menengah Pertama - Destu Kurniawan, Dwi Yulianti, Riswandi

DOI : https://doi.org/10.31004/edukatif.v3i4.1119

Media audio visual adalah alat bantu yang memperlihatkan gambar yang bergerak dan suara secara bersama-sama saat menyampaikan informasi atau pesan. Audio visual merupakan media yang efektif dalam menyampaikan informasi yang mencakup unsur gerak karena dapat memperlihatkan suatu peristiwa secara berkesinambungan dan yang menjadi model dalam penyampaian. Media pembelajaran digunakan mengaktifkan komunikasi dan interaksi pendidik dengan siswa pada saat berlangsungnya kegiatan mengajar. Lebih lanjut (Sadiman, 2018: 74) menuturkan bahwa media ajar dalam bentuk audio visual merupakan salah satu alat bantu dalam proses pembelajaran dan memiliki banyak kelebihan apabila diterapkan dalam proses pembelajaran.

Penggunaan media audio visual akan membantu siswa dalam mempelajari gerak secara teliti dan benar sehingga dapat membantu pelaksanaan proses pembelajaran secara baik dan berkualitas. Mengingat pentingnya media untuk mencapai tujuan pembelajaran yang diharapkan, maka penulis mencoba meneliti penerapan pembelajaran atletik dengan menggunakan media audio visual untuk meningkatkan prestasi lompat jauh gaya jongkok.

Pembelajaran dengan pendekatan SAVI adalah pembelajaran yang menekankan bahwa belajar haruslah memanfaatkan semua alat indra yang dimiliki siswa. Pendekatan SAVI (Somatis, Auditori, Visual, dan Intelektual) atau belajar dengan memanfaatkan alat indra merupakan teori yang dikemukakan oleh Dave Meier (Astuti, 2017: 72). Pendekatan SAVI merupakan inti dari Accelerated Learning (AL) atau pembelajaran yang dipercepat. AL menjadikan belajar terasa manusiawi karena menempatkan siswa sebagai pusat sasaran. Pembelajaran SAVI sejalan dengan gerakan Accelerated Learning (AL), maka prinsipnya juga sejalan dengan AL.

Menurut (Astuti, 2017: 72). Istilah SAVI kependekan dari Somatik (S) yang bermakna gerakan tubuh (hands-on, aktivitas fisik), yaitu belajar dengan mengalami dan melakukan. Auditori (A) bermakna bahwa belajar dengan mendengarkan, menyimak, berbicara, presentasi, argumentasi, mengemukakan pendapat, dan menanggapi. Visual (V) bermakna belajar menggunakan indra mata melalui mengamati, menggambar, mendemonstrasikan, membaca, menggunakan media dan alat peraga. Intelektual (I) bermakna bahwa belajar menggunakan kemampuan berpikir (minds-on) belajar dengan konsentrasi pikiran dan berlatih menggunakannya melalui bernalar, menyelidiki, mengidentifikasi, menemukan, mencipta, mengkonstruksi, memecahkan masalah, dan menerapkan.

Berdasarkan penelitian terdahulu, model pembelajaran SAVI dalam pembelajaran memberikan pengaruh yang baik. pembelajaran yang menerapkan SAVI memberikan hasil terhadap peningkatan motivasi dan hasil belajar maupun prestasi belajar. Peningkatan menyimak, peningkatan keterampilan. meningkatkan kemampuan pemecahan masalah dan berfikir kritis.

\section{METODE PENELITIAN}

Jenis penelitian ini adalah penelitian dan pengembangan (Research and Development / R\&D). Tahap utama langkah-langkah dalam penelitian dan pengembangan mengacu pada penelitian dan pengembangan yang dikembangkan oleh (Borg, W. R., \& Gall, 1983) yaitu (1) mengumpulkan informasi dan penelitian pendahuluan, (2) perencanaan; (3) produk pengembangan; (4) pengujian terbatas; dan (5) revisi produk akhir.Populasi dalam penelitian ini adalah para pendidik kelas VIII SMP N 1 Ambarawa. Teknik pengambilan sampel yang digunakan adalah teknik purposive sampling. Sampel penelitian adalah 5 (tiga) guru penjas dan guru MGMP Penjas Kec. Ambarawa. Teknik analisis data dalam penelitian ini menggunakan analisis deskriptif kualitatif teknik. Hasil analisis data digunakan sebagai dasar untuk merevisi produk yang dikembangkan. Itu pedoman penilaian dapat dilihat pada Tabel 1. 
2376 Pengembangan Media Pembelajaran Audio Visual Berbasis SAVI untuk Meningkatkan Prestasi Lompat Jauh Gaya Jongkok (Gaya Ortodok) Siswa Sekolah Menengah Pertama - Destu Kurniawan, Dwi Yulianti, Riswandi

DOI : https://doi.org/10.31004/edukatif.v3i4.1119

Tabel 1. Validasi Instrumen Analisis Skoring

\begin{tabular}{|c|c|c|}
\hline No & Pilihan Jawaban & Skor \\
\hline 1 & Sangat Baik & 5 \\
\hline 2 & Baik & 4 \\
\hline 3 & Cukup & 3 \\
\hline 4 & Kurang & 2 \\
\hline 5 & Sangat Kurang & 1 \\
\hline
\end{tabular}

Nilai yang diberikan adalah satu sampai lima untuk jawaban sangat baik, baik, cukup, kurang, dan sangat kurang. Data interval tersebut dapat dianalisis dengan menghitung rata-rata jawaban berdasarkan skoring setiap jawaban dari ahli.

$$
\text { Persentase Jawaban }=\frac{\text { Jumlah skor }- \text { Skor minimal }}{\text { Skor maksimal }- \text { skor minimal }} \quad x 100 \%
$$

Selanjutnya persentase kelayakan yang didapatkan kemudian diinterpretasikan ke dalam kategori kelayakan berdasarkan tabel. 2

Tabel 2. Kriteria Kelayakan

\begin{tabular}{cc}
\hline Skor Persentase (\%) & Interprestasi \\
\hline $0 \%-20 \%$ & Sangat tidak layak \\
\hline $21 \%-40 \%$ & Kurang layak \\
\hline $41 \%-60 \%$ & Cukup \\
\hline $61 \%-80 \%$ & Layak \\
\hline $81 \%-100 \%$ & Sangat layak \\
\hline
\end{tabular}

\section{HASIL DAN PEMBAHASAN}

Sebelum proses pengembangan produk, peneliti terlebih dahulu melakukan studi pendahuluan atau analisis kebutuhan melalui penyebaran kuesioner dengan subjek 20 (dua puluh) peserta didik. Kuesioner terdiri dari 15 pernyataan yaitu disusun berdasarkan aspek permasalahan belajar siswa, kebutuhan media pembelajaran, dan potensi peserta didik. Berdasarkan hasil angket permasalahan belajar siswa diperoleh hasil 82,5\% hal ini menunjukan bahwa peserta didik mengalami kesulitan belajar menggunakan teacher centered approaches sehingga perlu inovasi baru. Berdasarkan hasil angket kebutuhan media pembelajaran diperoleh hasil $83,7 \%$ hal ini menunjukan bahwa peserta didik membutuhkan media pembelajaran sebagai bahan ajar untuk pembelajaran atletik lompat jauh. Sedangkan untuk hasil angket potensi peserta didik diperoleh hasil $84,58 \%$ yang artinya peserta didik mempunyai potensi dan bahan ajar yang digunakan oleh guru masih kurang maksimal.

Media pembelajaran yang digunakan belum dapat mencapai proses pengembangan produk awal berdasarkan analisis kebutuhan dan penelaahan Inti Kompetensi dan Kompetensi Dasar. Media pembelajaran yang disusun kemudian akan divalidasi oleh validator ahli materi, validasi ahli desain dan validasi ahli media. Hasil validasi ahli dapat dilihat pada tabel 3.

Tabel 3. Hasil validasi ahli materi

\begin{tabular}{cllrcc}
\hline No & Aspek yang dinilai & Ahli 1 & Ahli 2 & Skor Ahli & Skor Maksimal \\
\hline 1 & Kelayakan Aspek Materi & 68 & 65 & 133 & 150 \\
2 & Kelayakan Aspek Kebahasaan & 35 & 32 & 68 & 70 \\
\hline
\end{tabular}


2377 Pengembangan Media Pembelajaran Audio Visual Berbasis SAVI untuk Meningkatkan Prestasi Lompat Jauh Gaya Jongkok (Gaya Ortodok) Siswa Sekolah Menengah Pertama - Destu Kurniawan, Dwi Yulianti, Riswandi

DOI : $\quad$ https://doi.org/10.31004/edukatif.v3i4.1119

\begin{tabular}{lllccc}
\hline 3 & Kelayakan Aspek Penyajian & 20 & 20 & 40 & 40 \\
4. & Kelayakan Strategi & 22 & 22 & 44 & 50 \\
5. & pembelajaran Kelayakan & 42 & 44 & 86 & 90 \\
& Aspek Menyeluruh & & & $\mathbf{3 6 8}$ \\
& & & & $\mathbf{4 0 0}$ \\
\hline & & & $\mathbf{9 2 \%}$ \\
\hline
\end{tabular}

Berdasarkan Tabel.3 dapat dilihat hasil validasi ahli materi berbasis SAVI Produk Media pembelajaran audio visual memperoleh persentase $92 \%$ dengan kriteria sangat layak digunakan. Selanjutnya hasil Validasi ahli desain dapat dilihat pada Tabel 4.

Tabel 4. Hasil validasi ahli desain

\begin{tabular}{cllrrc}
\hline No & Aspek yang dinilai & Ahli 1 & Ahli 2 & Skor Ahli & Skor Maksimal \\
\hline 1 & Kelayakan Aspek Materi & 65 & 65 & 130 & 150 \\
2 & Kelayakan Aspek Kebahasaan & 32 & 32 & 64 & 70 \\
3 & Kelayakan Aspek Penyajian & 20 & 20 & 40 & 40 \\
4. & Kelayakan Strategi & 23 & 22 & 45 & 50 \\
5. & pembelajaran Kelayakan & 42 & 44 & 86 & 90 \\
& Aspek Menyeluruh & & & $\mathbf{3 6 5}$ & $\mathbf{4 0 0}$ \\
\cline { 2 - 5 } & Skor & & & $\mathbf{9 1 , 2 5 \%}$ \\
\cline { 2 - 5 }
\end{tabular}

Berdasarkan Tabel. 4 terlihat bahwa nilai hasil validasi ahli desain berbasis SAVI Produk Media pembelajaran audio visual memperoleh persentase $91,25 \%$ dengan kriteria sangat layak digunakan. Selanjutnya hasil Validasi ahli media dapat dilihat pada Tabel. 5

Tabel 5. Hasil validasi ahli media

\begin{tabular}{clcccc}
\hline No & Aspek yang dinilai & Ahli 1 & Ahli 2 & Skor Ahli & Skor Maksimal \\
\hline 1 & Kelayakan Aspek Materi & 66 & 65 & 131 & 150 \\
2 & Kelayakan Aspek Kebahasaan & 35 & 30 & 65 & 70 \\
3 & Kelayakan Aspek Penyajian & 15 & 20 & 35 & 40 \\
4. & Kelayakan Strategi & 22 & 20 & 42 & 50 \\
5. & pembelajaran Kelayakan & 42 & 40 & 82 & 90 \\
& Aspek Menyeluruh & & & $\mathbf{3 5 5}$ & $\mathbf{4 0 0}$ \\
\cline { 2 - 6 } & Skor & & & $\mathbf{8 8 , 7 5 \%}$ \\
\cline { 2 - 5 }
\end{tabular}

Berdasarkan Tabel. 5 terlihat bahwa nilai hasil validasi ahli media berbasis SAVI Produk Media pembelajaran audio visual memperoleh persentase $88,75 \%$ dengan kriteria layak digunakan Melalui Proses revisi, produk yang siap diujicobakan terbatas pada guru (praktisi). Hasil Hasil validasi oleh guru dapat dilihat pada Tabel. 6

Tabel 6. Hasil validasi guru

\begin{tabular}{cccccccccc}
\hline & Gr & Gr & Gr & Gr & Gr & \multirow{2}{*}{ Skor } & Skor \\
No Aspek yang dinilai & 1 & 2 & 3 & 4 & 5 & & Mak \\
\hline
\end{tabular}


2378 Pengembangan Media Pembelajaran Audio Visual Berbasis SAVI untuk Meningkatkan Prestasi Lompat Jauh Gaya Jongkok (Gaya Ortodok) Siswa Sekolah Menengah Pertama - Destu Kurniawan, Dwi Yulianti, Riswandi

DOI : https://doi.org/10.31004/edukatif.v3i4.1119

$\begin{array}{lllllllll}1 & \text { Kesesuaian materi dalam media pembelajaran } & 15 & 16 & 16 & 18 & 17 & 82 & 100 \\ 2 & \text { Kesesuaian tampilan Media pembelajaran } & 18 & 17 & 14 & 18 & 16 & 83 & 100 \\ 3 & \text { Kemenarikan dan kemudahan penggunaan } & 29 & 27 & 24 & 23 & 25 & 128 & 150\end{array}$

\begin{tabular}{llrr}
\hline Skor & 293 & 350 \\
\hline Nilai & $\mathbf{8 3 , 7 1 \%}$ & \\
\hline
\end{tabular}

Berdasarkan Tabel 6 terlihat bahwa hasil penilaian Media pembelajaran pembelajaran audio visual atletik lompat jauh oleh guru berjumlah $83,71 \%$ dengan kriteria sangat layak.

Tabel 7. Hasil validasi peserta didik

\begin{tabular}{|c|c|c|c|c|c|c|c|c|}
\hline No & Aspek yang dinilai & $\begin{array}{l}\text { Sisw } \\
\mathbf{a} \\
1\end{array}$ & $\begin{array}{l}\text { Sisw } \\
\mathbf{a} \\
\mathbf{2}\end{array}$ & $\begin{array}{l}\text { Sisw } \\
\mathbf{a} \\
\mathbf{3}\end{array}$ & $\begin{array}{l}\text { Sisw } \\
\mathbf{a} \\
\mathbf{4}\end{array}$ & $\begin{array}{l}\text { Sisw } \\
\mathbf{a} \\
\mathbf{5}\end{array}$ & Skor & $\begin{array}{l}\text { Skor } \\
\text { Mak }\end{array}$ \\
\hline 1 & Kesesuaian materi dalam media & 16 & 17 & 17 & 15 & 18 & 83 & 100 \\
\hline 2 & pembelajaran & 17 & 18 & 17 & 16 & 16 & 84 & 100 \\
\hline 3 & $\begin{array}{l}\text { Kesesuaian tampilan Media } \\
\text { pembelajaran Kemenarikan dan } \\
\text { kemudahan penggunaan }\end{array}$ & 26 & 27 & 26 & 25 & 24 & 128 & 150 \\
\hline & Skor & & & & & & 295 & 350 \\
\hline & Niali & \multicolumn{7}{|c|}{$84,28 \%$} \\
\hline
\end{tabular}

Produk Media pembelajaran pembelajaran materi atletik lompat juah gaya jongkok yang dikembangkan dapat dilihat pada tabel 1-7. Setelah merevisi saran dan masukan dari ahli materi, ahli desain, ahli media dan guru, diperoleh produk akhir berupa Media pembelajaran pembelajaran audio visual atletik lompat jauh berbasis SAVI untuk siswa kelas VIII yang sangat cocok digunakan dalam pembelajaran.

Pengembangan media pembelajaran pembelajaran atletik lompat juah gaya jongkok (ortodok), produk yang dikembangkan telah memenuhi konsep pembelajaran dan pembelajaran. Berdasarkan landasan teori pembelajaran behavioristik. Belajar merupakan akibat adanya interaksi antara stimulus dan (Salavin, 2016: 42). Menurut (Desmita, 2014: 44) teori belajar behavioristik merupakan teori belajar memahami tingkah laku manusia yang menggunakan pendekatan objektif, mekanistik, dan materialistik, sehingga perubahan tingkah laku pada diri seseorang dapat dilakukan melalui upaya pengkondisian. Teori belajar behavioristik sangat menekankan pada hasil belajar, yaitu adanya perubahan perilaku yang dapat diamati, diukur dan dinilai secara konkret.

Menurut Vigotsky (Trianto, 2015: 23), proses belajar akan terjadi jika anak bekerja atau menangani tugas-tugas yang belum dipelajari, tetapi tugas-tugas itu masih dalam jangkauannya yang biasanya disebut zona perkembangan proksimal, yang merupakan tingkat perkembangan sedikit di atas kemampuannya. Ide penting lainnya dari Vigotsky adalah Scaffolding, yaitu memberikan bantuan kepada anak-anak pada tahap awal perkembangan dan mengurangi bantuan serta memberikan kesempatan kepada anak untuk mengambil alih tanggung jawab yang lebih besar setelah anak dapat melakukannya. Interpretasi terbaru dari ide-ide Vigotsky adalah bahwa siswa harus diberi tugas yang kompleks, sulit dan realistis yang kemudian diberikan bantuan yang cukup untuk menyelesaikan tugas (Tohir, 2015: 12).

Oleh karena itu, pengembangan Media Pembelajaran Audio Visual Berbasis SAVI Untuk Meningkatkan Prestasi Lompat Jauh Gaya Jongkok (Gaya Ortodok) dirancang agar siswa dapat mengamati, mengalaminya sendiri, dan memperoleh informasi yang tersedia di teks, gambar, animasi, audio, dan video 
2379 Pengembangan Media Pembelajaran Audio Visual Berbasis SAVI untuk Meningkatkan Prestasi Lompat Jauh Gaya Jongkok (Gaya Ortodok) Siswa Sekolah Menengah Pertama - Destu Kurniawan, Dwi Yulianti, Riswandi

DOI

$$
\text { : https://doi.org/10.31004/edukatif.v3i4.1119 }
$$

dengan alat bantu, navigasi atau langkah-langkah kegiatan, sehingga mendorong siswa untuk mengkonstruksi pengetahuan dengan pengalamannya sendiri.

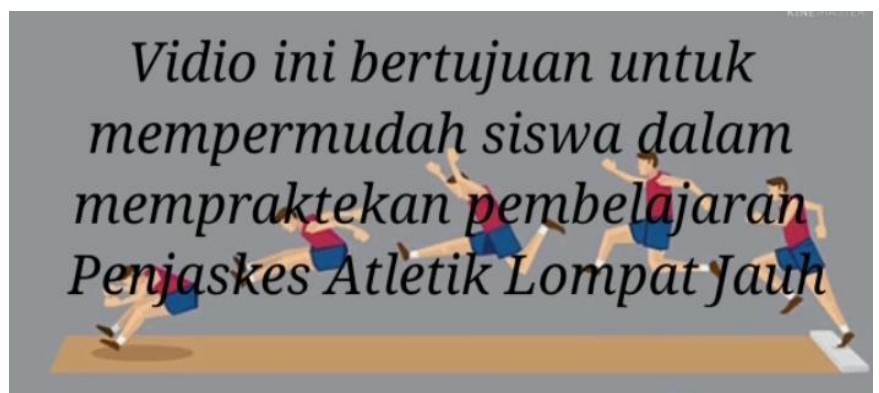

Gambar 1. Tampilan awal vidio

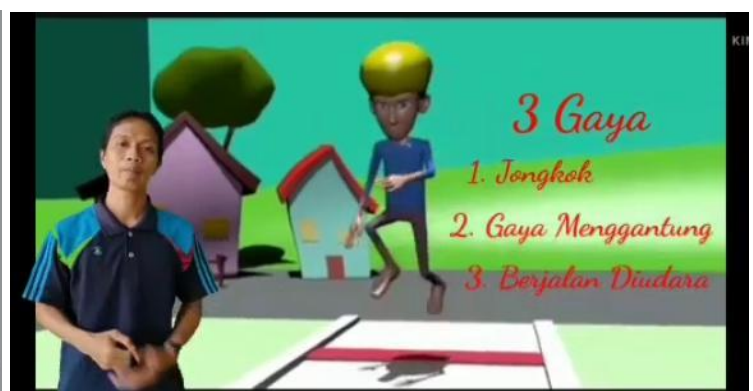

Gambar 2. Pengenalan Materi

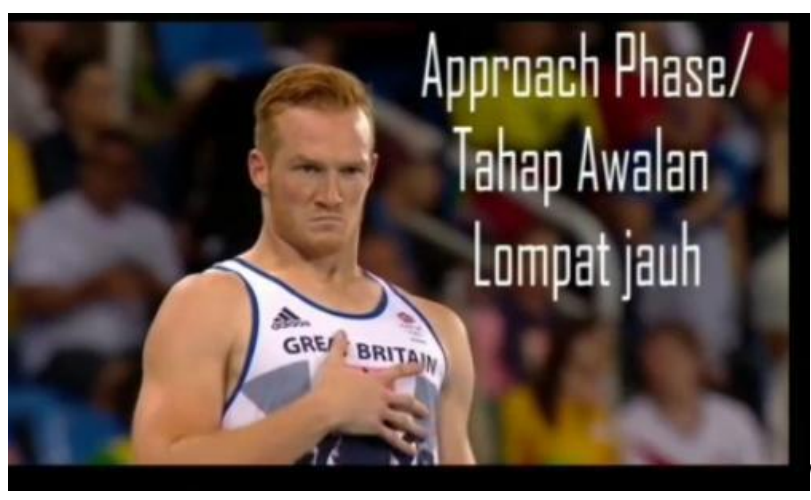

Gambar 3. Gerakan lompat jauh awalan

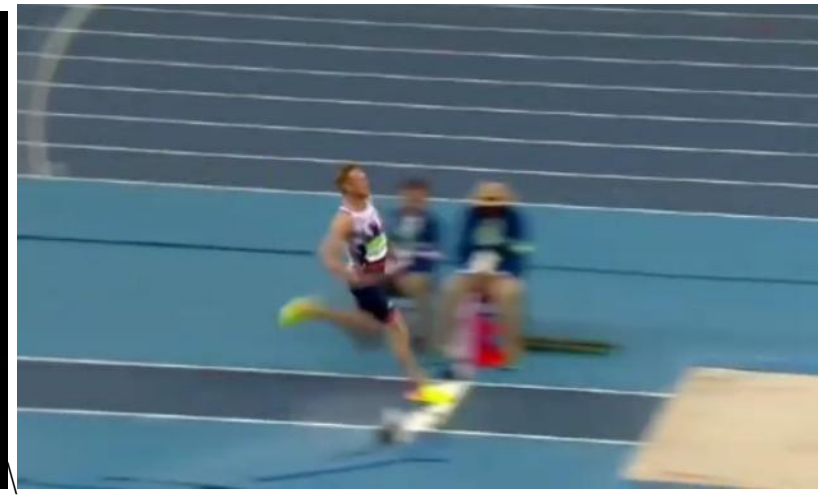

Gambar 4. Gerakan lompat jauh melompat

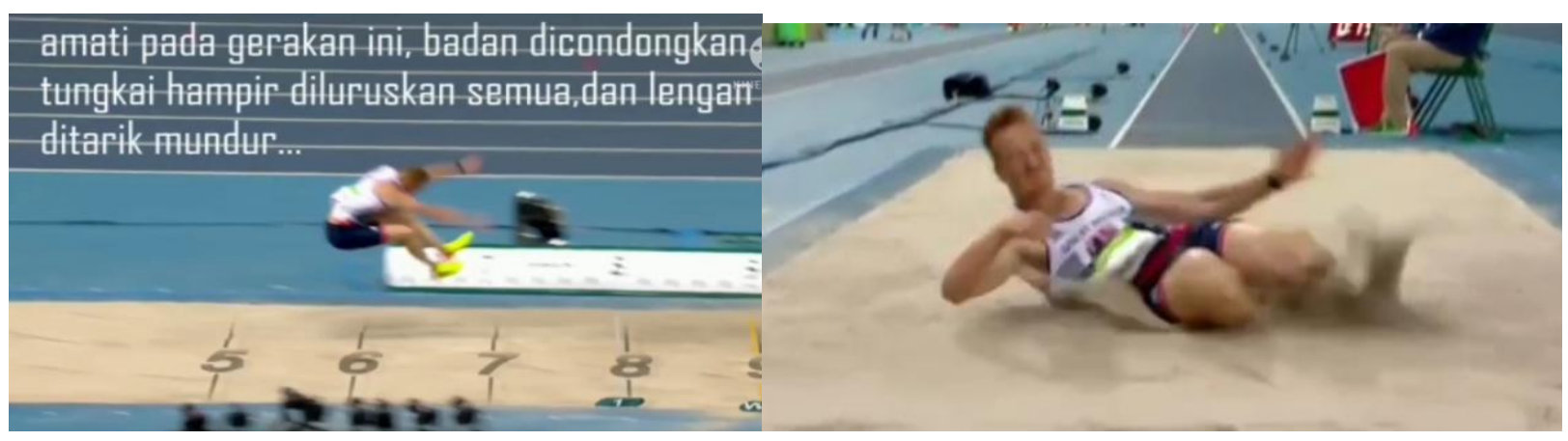

Gambar 5 . Gerakan lompat jauh melayang

Gambar 6. Gerakan lompat jauh mendarat

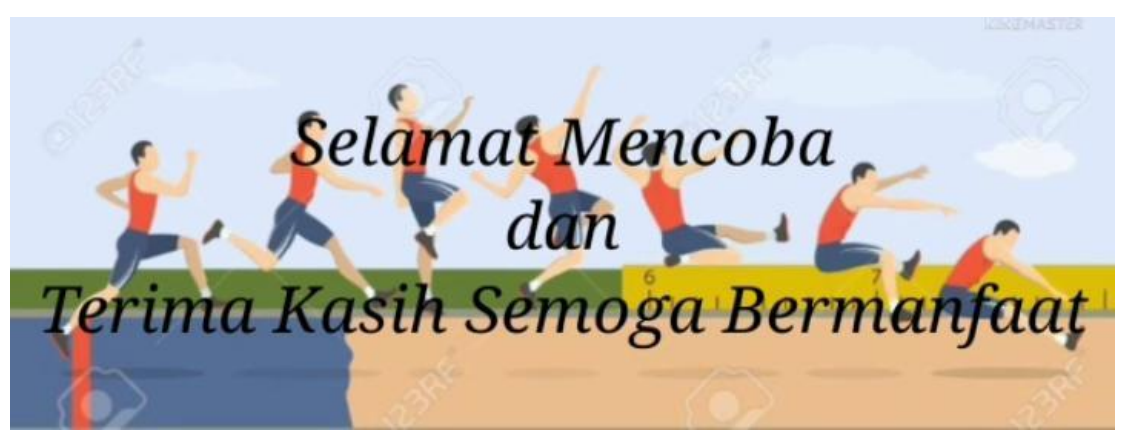

Gambar 7. Gambar penutup

Edukatif : Jurnal Ilmu Pendidikan Vol 3 No 4 Tahun 2021 p-ISSN 2656-8063 e-ISSN 2656-8071 
2380 Pengembangan Media Pembelajaran Audio Visual Berbasis SAVI untuk Meningkatkan Prestasi Lompat Jauh Gaya Jongkok (Gaya Ortodok) Siswa Sekolah Menengah Pertama - Destu Kurniawan, Dwi Yulianti, Riswandi

DOI : https://doi.org/10.31004/edukatif.v3i4.1119

Media pembelajaran pembelajaran audio visual materi lompat jauh gaya jongkok (gaya ortodok) dinilai sangat layak berdasarkan ahli materi, ahli desain, ahli media dan praktisi. Hasil penelitian ini didukung oleh penelitian yang dilakukan oleh (Prayugo \& Prihanto, 2015: 98). Hasil penelitian menunjukkan bahwa media pembelajaran Mata Pelajaran Penjas Materi ateltik lompat jauh dinilai sesuai dengan penilaian sangat layak. Selain itu, penelitian yang dilakukan oleh (Kurniawan, 2017: 52) dengan judul Penerapan Media Audio Visual Terhadap Hasil Belajar Lompat Jauh Gaya Jongkok dengan hasil penelitian dan pengembangan sangat baik. Hasil dari kedua uji coba tersebut dijadikan acuan untuk melakukan revisi produk tahap sehingga menghasilkan produk akhir media pembelajaran pembelajaran audio visual berbasis savi.

Selain itu, Alasan media pembelajaran menjadi solusi dalam penelitian ini adalah untuk memudahkan proses pembelajaran sehingga kesulitan belajar dapat teratasi. (Ginanjar, 2014: 25). mengatakan bahwa penggunaan media pembelajaran di kelas yaitu: (1) menjelaskan materi pembelajaran objek yang abstrak (tidak nyata) menjadi konkrit (nyata), (2) memberikan pengalaman langsung karena peserta dapat berkomunikasi dan berinteraksi dengan lingkungan tempat belajarnya, (3) mempelajari materi pembelajaran secara berulang-ulang, (4) memungkinkan adanya persamaan pendapat dan persepsi yang benar terhadap suatu materi pembelajaran atau objek,(4) menarik perhatian peserta didik, (5) membantu siswa belajar secara individual, kelompok dan klasikal, (6) materi pembelajaran lebih lama diingat dan mudah untuk diungkapkan kembali dengan cepat dan tepat, (7) mempermudah dan mempercepat pendidik menyajikan materi pembelajaran dalam proses pembelajaran, sehingga memudahkan peserta untuk mengerti dan memahami pesan atau materi yang disampaikan dengan jelas, (8) mengatasi keterbatasan ruang, waktu dan indra.

Menurut (Sudrajad, 2015: 45). Media pembelajaran dapat mengatasi keterbatasan pengalaman yang dimiliki oleh para peserta didik. Pengalaman tiap peserta didik berbeda-beda, tergantung dari faktor-faktor yang menentukan kekayaan pengalaman anak, seperti ketersediaan buku, kesempatan melancong, dan sebagainya. Media pembelajaran dapat mengatasi perbedaan tersebut. Jika peserta didik tidak mungkin dibawa ke objek langsung yang dipelajari, maka objeknyalah yang dibawa ke peserta didik. Objek dimaksud bisa dalam bentuk nyata, miniatur, model, maupun bentuk gambar-gambar yang dapat disajikan secara audio visual.

Apa yang telah dijelaskan di atas telah menunjukkan bahwa pentingnya mengembangkan media pembelajaran pengembangan media pembelajaran audio visual berbasis savi untuk meningkatkan prestasi lompat jauh gaya jongkok (gaya ortodok). Media pembelajaran ini sebagai motivasi, minat belajar, materi lebih efektif dan efisiensi . Dengan bantuan media pembelajaran Siswa siswa bisa belajar dengan mandiri dan interaksi siswa semakin meningkat. Secara keseluruhan, penelitian ini telah memberikan pengembangan produk yang telah dirancang dan divalidasi sesuai aturan. Hasil data juga menunjukkan bahwa produk yang dikembangkan layak digunakan dalam pembelajaran.

\section{KESIMPULAN}

Media Pengembangan Media Pembelajaran Audio Visual Berbasis SAVI Untuk Meningkatkan Prestasi Lompat Jauh Gaya Jongkok (Gaya Ortodok) Pada Siswa Kelas VIII SMP Di Kabupaten Pringsewu telah memberikan satu alternatif bagi guru dalam meningkatkan proses belajar dan mengajar. Penelitian pengembangan ini telah menghasilkan media pembelajaran pembelajaran audio visual. Media pembelajaran Pembelajaran Audio Visual Berbasis SAVI Untuk Meningkatkan Prestasi Lompat Jauh Gaya Jongkok (Gaya Ortodok) telah melalui uji validitas oleh pakar dan dosen yang ahli di bidangnya. Dengan uji validitas ini maka media pembelajaran ini talah dikategorikan valid.

Berdasarkan hasil penelitian dan pembahasan dapat disimpulkan bahwa pengembangan Media pembelajaran Pembelajaran Audio Visual Berbasis SAVI Untuk Meningkatkan Prestasi Lompat Jauh Gaya 
2381 Pengembangan Media Pembelajaran Audio Visual Berbasis SAVI untuk Meningkatkan Prestasi Lompat Jauh Gaya Jongkok (Gaya Ortodok) Siswa Sekolah Menengah Pertama - Destu Kurniawan, Dwi Yulianti, Riswandi

DOI : https://doi.org/10.31004/edukatif.v3i4.1119

Jongkok (Gaya Ortodok) Pada Siswa Kelas VIII SMP Di Kabupaten Pringsewu layak untuk dilakukan digunakan dalam pembelajaran. Hal tersebut berdasarkan hasil validasi ahli materi sebesar $92 \%$, hasil validasi ahli desain sebesar $91,25 \%$, hasil validasi ahli media sebesar $88,75 \%$, hasil tes kepada guru sebesar $83,71 \%$ dan hasil tes siswa sebesar $84,28 \%$.

Media pembelajaran Pembelajaran Audio Visual Berbasis SAVI Untuk Meningkatkan Prestasi Lompat Jauh Gaya Jongkok (Gaya Ortodok) ini dapat menjadi motivasi bagi guru untuk mempergunakannya dalam proses pembelajaran di kelas. Kepala sekolah dapat merekomendasikan kepada guru di sekolah dengan harapan dapat menjadi motivasi dalam merancang media pembelajaran pembelajaran audio visual yang sesuai kebutuhan siswa. Bagi guru, berdasarkan hasil validasi maka Media pembelajaran Pembelajaran Audio Visual Berbasis SAVI Untuk Meningkatkan Prestasi Lompat Jauh Gaya Jongkok (Gaya Ortodok) ini dapat menjadi salah satu pilihan bagi guru dalam menciptakan kegiatan belajar yang lebih bermakna.

\section{DAFTAR PUSTAKA}

Arsyad, Azhar, (2015). Media Pembelajaran. Jakarta: Raja Grafindo Persada.

Borg, W. R., \& Gall, G. (1983). Educational Research: An Introduction, Fifth Edition. Longman.

Depdiknas. (2017). Standar Pengelolaan Pendidikan Oleh Satuan Pendidikan Dasar Dan Menengah (Jakarta). Jakarta : Depdiknas.

Desmita, Desmita (2014). Psikologi Perkembangan Peserta Didik. Remaja Rosdakarya.

D Ekiz, S., \& Kulmetov, Z. (2016). The Factors Affecting Learners' Motivation In English Language Education. Journal of Foreign Language Education And Technology, 1(1), 18-38. Http://Jflet.Com/Jflet/

Ginanjar, A. (2014). Pengembangan Media Pembelajaran Model Interaktif Mata Kuliah Pemindahan Tanah Mekanik. Skripsi Media $\quad$ Pembelajaran, 1 Https://Digilib.Uns.Ac.Id/Dokumen/Detail/17317/Pengembangan-Media-Pembelajaran-ModulInteraktif-Mata-Kuliah-Pemindahan-Tanah-Mekanik.

Kurniawan, (2015). Penerapan Media Audio Visual Terhadap Hasil Belajar Lompat Jauh Gaya Jongkok. Jurnal: Pendidikan Olahraga, 1(1), 43-55.

Mallikharjuna, (2014). Penilaian Hasil Proses Belajar Mengajar. Bandung: Remaja Rosdakarya.

Prayugo \& Prihanto, (2015). Penerapan Media Belajau Audio Visual Untuk Pembelajran Siswa Materi Lompat Jauh Siswa SMK. Jurnal Pendidikan Vokasi, Volume .2 Nomor 3. 2015.

Rahmani Astuti. (2017). The Accelerated Learning Handbook - Panduan Kreatif Dan Efektif Merancang Program Pendidikan Dan Pelatihan (Dave Meier. Terjemahan). Bandung: Kaifa.

Sadiman, Dkk. (2018). Media Pendidikan, Pengertian, Pengembangan, Dan Pemanfaatannya. Jakarta: PT Raja Grafindo Persada.

Slavin, R.E. (2016). Educational Psychology: Theory And Practice. Massachusetts: Allyn And Bacon.

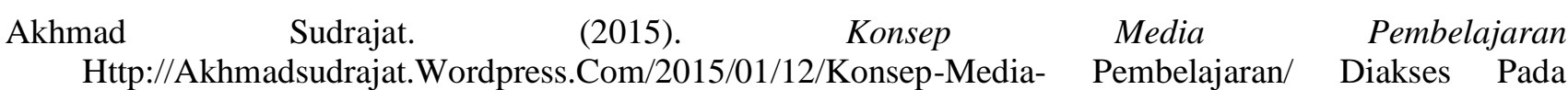
Tanggal 7 Februari 2021 Waktu 21.20 WIB.

Sugihartono, Dkk, (2012). Psikologi Pendidikan, Yogyakarta: UNY Press.

Suherman, A. (2012). Revitalisasi Pengajaran Dalam Pendidikan Jasmani. Bandung: Bintang Warliartika

Sukariasih, L., Erniwati, E., \& Salim, A. (2019). Development Of Interactive Media Pembelajaran On Science Learning Based Adobe Flash CS6. International Journal For Educational And Vocational Studies, 1(4), 
2382 Pengembangan Media Pembelajaran Audio Visual Berbasis SAVI untuk Meningkatkan Prestasi Lompat Jauh Gaya Jongkok (Gaya Ortodok) Siswa Sekolah Menengah Pertama - Destu Kurniawan, Dwi Yulianti, Riswandi

DOI : https://doi.org/10.31004/edukatif.v3i4.1119

322-329. Https://Doi.Org/10.29103/Ijevs.V1i4.1454Wiarto, Giri. (2013). Atletik Lompat Jauh Gaya Ortodok. Yogyakarta: Graha Ilmu.

Tohir, A. (2015). Pengembangan Audio Visual Materi Atletik Lompat Jauh Berbasis Multipel Representasi Di SMA Kota Bandar Lampung. Program Pascasarjana Teknologi Pendidikan Fakultas Keguruan Dan Ilmu Pendidikan Universitas Lampung.

Trianto. (2015). Model Pembelajaran Terpadu. Bumi Aksara.

Wijoyo, H., \& Girirya, S. (2020). Pengaruh Pengembangan Audio Visual Berbasis Savi Pada Perkembangan Fisik-Motorik Peserta Didik Di Sekolah Dasar. Jurnal Undiksa, 1(1), 19-24. Https://Maitreyawira.E-Journal.Id/Jm/Article/Viiiew/18. 